\title{
THE TEMPERATURE OF PEAT SOIL AT LETEENSUO
}

\author{
YRJö Pessi \\ Society of Peat Cultivation, Experimental Station Leteensuo
}

Received November 14, 1961.

The thermal conditions in peat soil have been investigated in Finland over prolonged periods particularly at the Frost Research Station at Pelsonsuo (2, 3, 4, 5). The location of Pelsonsuo $\left(26.5^{\circ} \mathrm{E}, 64.3^{\circ} \mathrm{N}\right)$ is so northerly that conditions there are distinctly different from conditions in South-Finland. At the experimental station Leteensuo of the Society of Peat Cultivation $\left(24.15^{\circ} \mathrm{E}, 61.04^{\circ} \mathrm{N}\right)$ certain investigations concerning soil temperatures have been carried out since 1958. Their aim was mainly to obtain a general idea of the thermal conditions prevailing in cultivated peat soil and also in some bogs in their natural state when their location is more southerly.

\section{Method of investigation}

The soil temperatures were measured with the equipment described in detail in a previous publication (6). Measurements were made at depths of 20,50 and 100 $\mathrm{cm}$ usually on the 1st and the 15th of each month, that is, at intervals of about two weeks. During the winter months measurements were made more infrequently,

during the time January to March only about twice. The depths of measurement representing a level where the diurnal temperature variations are hardly felt (4, p. 32), measurements were made only once daily. The measuring cycle was always commenced at 14.00 hours.

\section{Objects of investigation}

Measurements were made on cultivated fen land, on cultivated Sphagnum bog and on Sphagnum bog in the natural state.

The cultivated fen soil had a location where the thickness of the peat layer was about $2.5 \mathrm{~m}$. The peat was well-humified forest sedge peat. The peat in the tilled layer had a volume weight of 0.412 , computed for the ash-free, dry peat, and its ash content was $45 \%$ of the weight of the dry peat. The area has been in cultivation since 1905 . In the years of investigation, 1958-1960, spring cereal grew on the site of measurement. 
The c u l t i v a t e d S ph a g n u m bog had a peat layer of $3.5 \mathrm{~m}$ thickness, derived from Sph. fuscum. Apart from the tilled layer, the peat was only slightly humified, $\mathrm{H}_{1}$ according to von Post. The volume weight of the peat in the tilled layer, stated for the dry, ash-free peat, was 0.290 and its ash content was $53 \%$ of the weight of the dry peat. The area has been in cultivation since 1923. It has received clay as soil improving agent at the rate of $300 \mathrm{~m}^{3}$ per hectare. Spring cereal grew on the site of measurement in the years of investigation.

The Sphagnum bog in the natural state was of the pine bog type with many subshrubs (Fig. 1). Its peat layer was about $3.5 \mathrm{~m}$ in thickness. The pine stand of stunted growth was sparse; it consisted of trees about $2-3 \mathrm{~m}$ in height and shaded about $50 \%$ of the soil surface on sunny days. The site of measurement of about $3 \mathrm{~m}^{2}$ area was free of shrubs and covered with a continuous

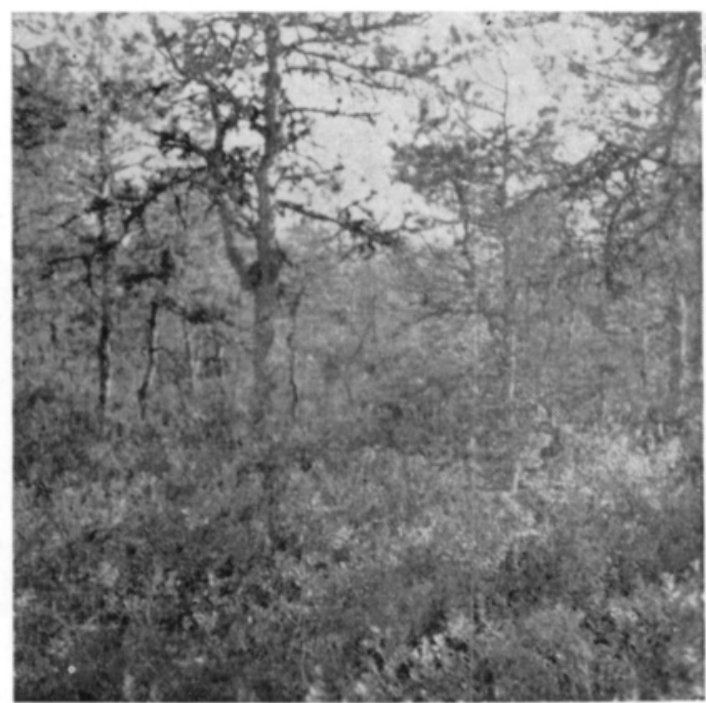

Fig. 1. The site of measurement on the Sphagnum bog in its natural state.

moss vegetation (Spleurozium Schreberi), and surrounded by shrubs (Ledum palustre, Vaccinium uliginosum). From the soil surface downwards there was a loose moss layer about $15 \mathrm{~cm}$ in thickness, followed by unhumified Sphagnum peat ( $S p h$. fuscum). The ash content of the Sphagnum peat was $1.5 \%$ of the weight of the dry peat and the volume weight of the ash-free, dry peat was 0.190 . The top layer at the site of measurement was thus of a kind that rather efficiently prevents exchange of heat from taking place between the soil and the air. On the other hand the windshield provided by the trees contributed rather strongly to the increase of the air temperature in the afternoon.

All measurements were made in spots where the ground water table varied between 40 and $100 \mathrm{~cm}$ below soil surface, although it was transiently higher at the time when the snow melted. 


\section{Weather conditions}

The normal temperature and rainfall values at Leteensuo, based on 30 years' records, are shown in the accompanying Table 1 , which also contains the average deviation from normal of the monthly means during the time of investigation (1. VI. 1958-31. V. 1961). It can be seen that the period of these investigations has been somewhat less rainy than normal and slightly warmer than normal.

In two of the winters the ground was frozen to a depth of $10-20 \mathrm{~cm}$, but no frozen ground occurred in the third winter. A snow cover has usually existed from December to March.

Table 1. Normal temperature and rainfall values at Leteensuo and Pelsonsuo (1921-1950) and average deviation from normal of the monthly means during the periods of investigation (1. VI. 1958-31. V. 1961 at Leteensuo; 1 . X. 1952-30. IX. 1955 at Pelsonsuo)

Leteensuo:

Normal mean

temperature, ${ }^{\circ} \mathrm{C}-7.4-7.8-3.8$

Deviation $\quad+0.2+2.7+1.4$

Normal rainfall, mm $\quad 37 \quad 31 \quad 34$

$\begin{array}{rrrrrr}2.4 & 9.4 & 13.9 & 17.2 & 15.1 & 10.0\end{array}$

$\begin{array}{cccccc}0.0 & +0.9 & +0.6 & -0.4 & -0.3 & -0.7\end{array}$

$\begin{array}{lll}4.1 & -0.2 & -4.0\end{array}$

4.1

Deviation

$\begin{array}{lll}+3 & -9 & -16\end{array}$

35

$\begin{array}{rrrrr}42 & 56 & 71 & 74 & 65\end{array}$

$\begin{array}{llll}0.0 & +0.7 & -1.1 & +0.3\end{array}$

$\begin{array}{llllll}-11 & -6 & -8 & -6 & -11 & -32\end{array}$

$-33$

$\begin{array}{lrr}46 & 43 & 597\end{array}$

Pelsonsuo:

Normal mean

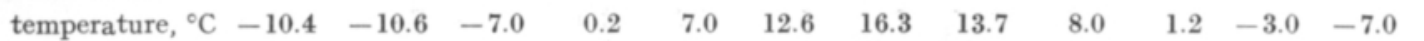

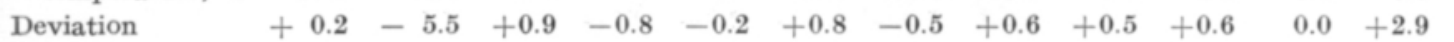

0.0

Deviation

$-11+3+14+6+14$

\section{Results of investigation}

As measurements were only made twice every month during the summertime and even less frequently in the winter months, the significance of the present results is mainly, as already stated, that one obtains a general idea of the thermal conditions. The treatment of the results consisted of graphic plotting of the course of the temperature in each year at different depths in the soil, after which the annual variation of the temperature was plotted as the mean of the results referring to the three years. The graphs are shown in Fig. 2, in which also the corresponding temperature graphs from Pelsonsuo, representing the means of the years $1952-1955,(4$, p. 27$)$ have been included. With respect to the site of measurement the investigations at Pelsonsuo would in the first hand be comparable to the observations made on the cultivated fen soil at Leteensuo.

Mutual comparison of the results from Leteensuo reveals that the temperature at the investigated depths has been highest in the summertime on the cultivated fen, the cultivated Sphagnum bog ranging next, and that on the Sphagnum bog in its natural state being lowest. Relating the results from Leteensuo and Pelsonsuo 


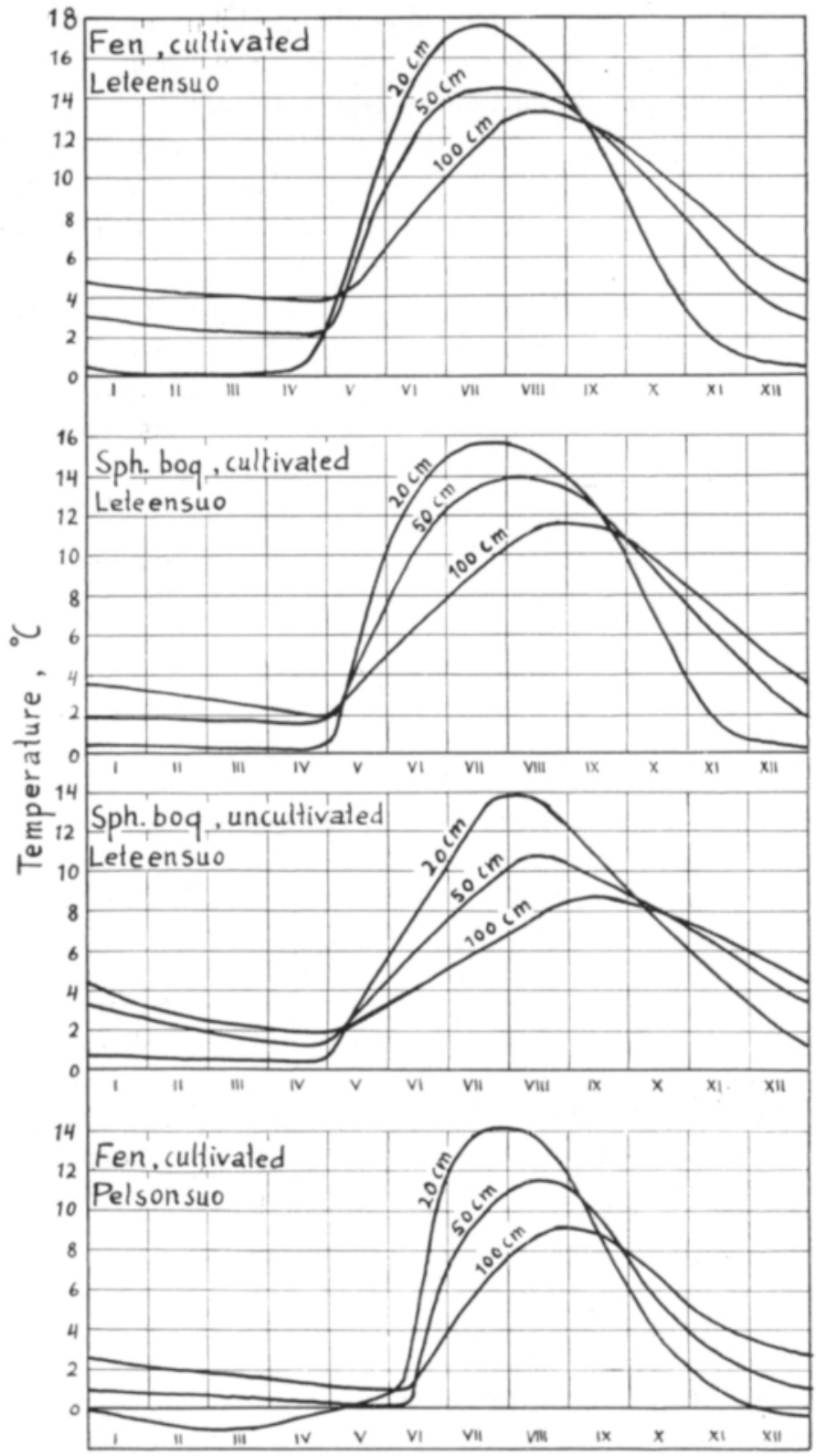

Fig. 2. The annual variation of the soil temperature at different points of measurement at Leteensuo, as means from the observations of three years, and corresponding graph from observations at Pelsonsuo relating to a period of the same length but not coinciding with the investigation at Leteensuo.

to each other one finds that the soil temperature at Pelsonsuo during the period in question (1952 - 1955) has been lower than on the cultivated bog areas at Leteensuo in 1958-1961. Another highly distinct difference consists of the fact that at Pelsonsuo the soil temperature has begun to increase more than one month later than at Leteensuo. Although the growth of plants is primarily affected by the thermal con- 
ditions of the layers very close to the soil surface, which are not elucidated by the present investigation, the general inference can be drawn from the results presented here that thermal conditions in cultivated bog lands will be more favourable with a view to the cultivation of plants in South-Finland than at higher latitudes. One of the factors acting in this direction is the much earlier time at which the soil begins to warm up in the southern parts of the country and the corresponding later cooling of the soil.

Conditions at Leteensuo and Pelsonsuo with respect to nitrogen mobilization can probably best be compared on the basis of the results presented in Table 2, which contains the effective heat quantity at different depths in the soil, the limiting temperature being taken as $+5^{\circ} \mathrm{C}$, as KERÄNEN $(1, \mathrm{p} .141)$ has done in his calculations

Table 2. The effective temperature figure $\left(\sum_{m=1}^{n}\left(t_{m}-5^{\circ} \mathrm{C}\right)\right)$ for different depths in cultivated fen soil at Leteensuo and Pelsonsuo.

\begin{tabular}{|c|c|c|c|c|c|c|c|c|c|c|}
\hline Depth & Locality & May & June & July & August & Sept. & Oct. & Nov. & Dec. & Total \\
\hline \multirow[t]{2}{*}{$20 \mathrm{~cm}$} & Leteensuo & 70.4 & 279.0 & 385.0 & 337.9 & 201.0 & 40.0 & - & - & 1314 \\
\hline & Pelsonsuo & - & 52.4 & 266.6 & 263.5 & 117.0 & 3.0 & - & - & 702 \\
\hline \multirow[t]{2}{*}{$50 \mathrm{~cm}$} & Leteensuo & 37.8 & 201.0 & 288.3 & 285.2 & 219.0 & 139.5 & 36.0 & - & 1207 \\
\hline & Pelsonsuo & - & 7.5 & 133.3 & 198.4 & 135.0 & 19.2 & - & - & 493 \\
\hline \multirow[t]{2}{*}{$100 \mathrm{~cm}$} & Leteensuo & 7.0 & 96.0 & 198.4 & 254.2 & 219.0 & 170.5 & 93.0 & 14.0 & 1045 \\
\hline & Pelsonsuo & - & - & 30.8 & 117.8 & 111.0 & 46.5 & - & - & 306 \\
\hline
\end{tabular}

of the effective heat quantity in the air during the growing season. At $20 \mathrm{~cm}$ depth the effective heat is nearly twice as high at Leteensuo as the corresponding value found for Pelsonsuo and at greater depths even three times as high.

This difference in thermal conditions is clearly evident in actual practice, e.g. in a different mobilization of nitrogen in bogs of different geographic location with consequent differences in required nitrogen fertilization.

\section{$S u m m$ ary}

The soil temperature at depths of 20,50 and $100 \mathrm{~cm}$ has been higher in the summertime in the cultivated fen soil at Leteensuo than in cultivated Sphagnum peat soil, while the latter again had higher temperatures than Sphagnum bog in its natural state. There is a remarkable difference in soil temperature between two bogs of different geographical location, namely, Leteensuo and Pelsonsuo. At Leteensuo, which lies in the southern part of Finland, the soil begins to warm up at a much earlier date than at Pelsonsuo and the soil temperature is higher. The effective soil temperature (referred to $+5^{\circ} \mathrm{C}$ ) at $20 \mathrm{~cm}$ depth is nearly twice as high as at Pelsonsuo; at a greater depth it is even three times as high. 


\section{REFERENCES:}

(1) KeRÄNEN, J. 1942. Lämpötalous ja lämpötila maatalousilmastollisina tekijöinä Suomessa. Referat: Wärmehaushalt und Temperatur als agrarklimatologische Faktoren in Finnland. Terra 54: $132-151$.

(2) Pessi, Y. 1956. Studies on the effect of the admixture of mineral soil upon the thermal conditions of cultivated peat land. Selostus: Tutkimuksia kivennäismaan sekoituksen vaikutuksesta suoviljelyksen lämpöoloihin. Valt.maatal. koetoim. julk. 147: 1-89.

(3) - - 1957. On the thermal conditions in mineral and peat soil at Pelsonsuo in 1955-1956. Selostus: Kivennäismaan ja turvemaan lämpöoloista Pelsonsuolla vuosina 1955-1956. Valt. maatal. koetoim. julk. 159: 1-40.

(4) - - 1957 b. Suoviljelyksen maan lämpöoloista Pelsonsuolla vuosina 1952-1955. Summary; On the thermal conditions of cultivated peat soil in Pelsonsuo in the years 1952-1955. Valt. maatal. koetoim. julk. 154: 1-47.

(5) - 1958. On the influence of bog draining upon thermal conditions in the soil and in the air near the ground. Acta Agric. Scand. VIII: 4, pp. 359-374.

(6) - 1959. On the effect of liming upon the thermal conditions of Sphagnum bog. Selostus: Kalkituksen vaikutuksesta rahkasuon lämpötilaan. Suo 10:46-50.

S E L O T U S :

SUON LÄMPÖTILASTA LETEENSUOLLA

YRJö Pessi

Suoviljelysyhdistys, Leteensuon koeasema

Tutkimuksessa on selostettu Leteensuolla 1. 6. 1958-31. 5. 1961 suoritettuja maan lämpötilan mittauksia. Tutkimuskohteina olivat muta- ja rahkasuoviljelykset sekä luonnontilainen rahkasuo. Tuloksia on verrattu aikaisemmin Pelsonsuolla suoritettujen mittausten tuloksiin.

Leteensuon mutasuoviljelyksen maan lämpötila on ollut kesäisin 20,50 ja $100 \mathrm{~cm}$ :n syvyyksissä korkeampi kuin rahkasuoviljelyksen. Viljelty rahkasuo on vuorostaan ollut lämpimämpi kuin luonnontilainen. Leteensuolla maan lämpeneminen alkaa huomattavasti aikaisemmin kuin Pelsonsuolla ja lämpötila on myös korkeampi. Tehoisa lämpömäärä $\left(>+5^{\circ} \mathrm{C}\right)$ on Leteensuon mutasuoviljelyksellä ollut $20 \mathrm{~cm}: n$ syvyydessä lähes kaksinkertainen Pelsonsuon vastaavaan arvoon verrattuna, syvemmällä jopa kolminkertainen. Tämä lämpöolojen eroavuus maantieteelliseltä sijainniltaan erilaisissa soissa ilmenee mm. typen mobilisaation erilaisuudessa sekä siitä johtuvana erilaisena typpilannoituksen tarpeena soita viljeltäessä. 